May 9, 1996

$$
\text { DOE/PC/95050--13 }
$$

Report Number: DOE/PC 95050-13

\title{
CONTRACT TITLE AND NUMBER:
}

Exploratory Research on Novel Coal Liquefaction Concept

DOE Contract No. DE-AC22-95PC95050

\section{CONTRACTOR NAME:}

CONSOL InC.

Research \& Development

4000 Brownsville Road

Library, PA 15129

CONTRACT INITIATION DATE: May 24, 1995

ANTICIPATED COMPLETION DATE: May 23, 1998

GOVERNMENT AWARD: $\$ 1,314,477$ Total, $\$ 740,000$ Obligated

PRINCIPAL INVESTIGATORS: F. P. Burke, S. D. Brandes, and

SUBCONTRACTORS/PRINCIPAL INVESTIGATORS:

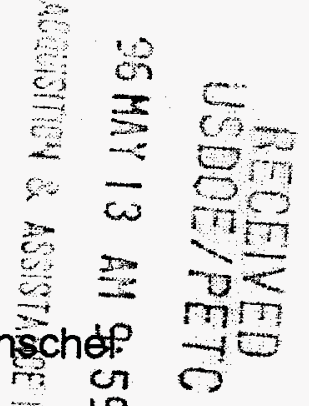

- University of Kentucky Center for Applied Energy Research - F. J. Derbyshire, G. Kimber, R. K. Anderson, S. D. Carter

- LDP Associates - M. Peluso

CONTRACTING OFFICER'S REPRESENTATIVE: M. A. Nowak

REPORTING PERIOD: January 1 through March 31, 1996

CONTRACT OBJECTIVES: No Change

\section{SUMMARY OF TECHNICAL PROGRESS - OVERALL}

Activities this quarter were conducted under Tasks 2 and 5 . Task 2 work was concentrated on evaluating the effects of low-severity, first-stage reaction conditions on coal conversions, exploring the effect of solvent-to-coal ratio on filtration performance, exploring the effects of pretreatment on dispersed catalysts for hydrotreating tests, and the installation and calibration of a simulated distillation instrument. Task 5 work included continued review of the technical and patent literature and expansion of the annotated bibliography.

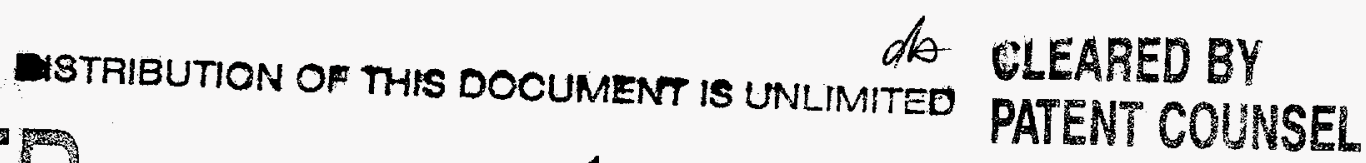




\section{DISCLAIMER}

Portions of this document may be illegible in electronic image products. Images are produced from the best available original document. 
Key accomplishments are the following:

- Coal conversions with Glenharold lignite, and high- and low-sodium content Freedom Mine lignite were improved by increasing the autogenic pressure of the reaction. Conversions obtained with Glenharold Mine lignite at $350^{\circ} \mathrm{C}$ were $>92$ wt $\%$, MAF basis.

- The one-liter reactor system construction was completed; shakedown runs were executed. Two sets of reaction conditions were used to produce large quantities of first-stage reaction products for filtration tests and second-stage hydrotreating tests.

- Coal conversions were found to be similar for runs made at two different solvent-tocoal ratios (1:1 and 1.5:1) with all other conditions the same.

- Material and elemental balance work was initiated for three microautoclave tests made with Black Thunder Mine subbituminous coal.

- Pretreatment tests conducted with Molyvan L prior to second-stage hydrotreating tests, over the range of conditions used, showed no discernable effect on Molyvan $L$ catalyst activity.

- Reaction time and temperature in second-stage hydrotreating tests were investigated in preparation for testing with first-stage filtrates.

- Filtration rates, although on the order of $10^{10} \mathrm{~m} / \mathrm{kg}$ were found to be lower for samples made with solvent-to-coal ratios of 1 or 1.5 than for samples with the higher (2:1) solvent-to-coal ratio previously tested.

- The catalytic effect of sodium on coal conversion was investigated. No effect was observed with the addition of sodium in catalytic amounts to the reaction system nor was there an increase in coal conversion with a high-sodium content sample of 
Freedom Mine lignite over that obtained previously with the low-sodium content sample.

\section{SUMMARY OF TECHNICAL PROGRESS - BY TASK:}

\section{Task 2 - Evaluation of Process Steps}

\section{Microautoclave Tests}

Microautoclave runs were made in which sodium was added to Freedom Mine North Dakota lignite to evaluate its possible catalytic effects. For these tests, the sodium was added as a sodium salt of an organic acid. This salt is a potential hydride ion source (hydride ion reagent " $\mathrm{C}$ "), but for these tests, it was added only in catalytic amounts. The sodium salt was introduced to the coal as a water solution at a level equivalent to increasing the sodium in the coal to 11 wt \% (as $\mathrm{Na}_{2} \mathrm{O}$ on ash). The coal-sodium salt mixture was allowed to air dry to the same moisture level as the starting coal. Microautoclave tests were made with this coal, hydride ion reagent " $A$ ", and Wilsonville Run 262E V1074 distillate solvent at $350^{\circ} \mathrm{C}$, for $30 \mathrm{~min}$ (Run 66) and for $60 \mathrm{~min}$ (Run 62). Coal conversions were 63.8 and $74.3 \mathrm{wt} \%$, respectively, approximately the same as when the coal was tested at the same conditions without the added sodium salt (58.0 and $72.3 \mathrm{wt} \%$, respectively). Runs 65 and 67 were made at the same conditions as Runs 66 and 62, except that three times the amount of sodium salt was added to the coal. The sodium salt was introduced as a water solution; the coal-sodium salt mixture was tumbled for 72 hours to ensure good mixing, and was partially air dried. The moisture content of the feed coal increased by about $12 \%$ (MF coal basis) from the procedure. Coal conversions, 58.1 and $74.6 \mathrm{wt} \%$, respectively were similar to the results with no added sodium.

Microautoclave runs were made with the same sodium salt as the sole hydride ion reagent (hydride ion reagent " $C$ "). In Run 68, the sodium salt was added as a dry solid in an equimolar amount to the hydride ion reagent " $\mathrm{A}$ " used in the previous tests. Run conditions were $350^{\circ} \mathrm{C}$ for $60 \mathrm{~min}$, sodium salt/dry coal: $1.2 \mathrm{w} / \mathrm{w}$, and solvent/dry coal: $2.2 \mathrm{w} / \mathrm{w}$. Coal conversion was not determined for this test, but the yield of non-gaseous solubles was $77.1 \%$ MAF. Gas yield was lower than in runs made under the same conditions with hydride ion reagent "A" ( $28 \%$ vs. about $80 \%$ MF). Run 69 was made at the same 
conditions except that the sodium salt was introduced as a water solution. The coal was slurried in the sodium salt solution and some of the moisture was evaporated under a stream of $\mathrm{N}_{2}$; the moisture content of the feed coal increased by $68 \%$ (MF coal basis) from the treatment. The THF-insoluble reaction products were water washed to remove residual sodium salts. Coal conversion based on the water washed THF-insolubles was 76.5 wt \%. Conditions in Runs 71 and 72 were the same as in Run 69, except that the coal was dried to its starting moisture content. Coal conversions based on water-washed THF insolubles were $77.0 \mathrm{wt} \%$ and $76.5 \mathrm{wt} \%$, respectively.

A sample of Freedom Mine North Dakota lignite (about $10 \mathrm{lb}, 1 / 4$ " top size) was received from Coteau Properties. This auger sample represents a high sodium content location in the coal seam. The entire sample was air dried and riffled, and a one-pound aliquot was split out, ground, and analyzed. The remainder of the sample was stored in triple-layer bags. In addition to having more sodium than the production sample $\left(\mathrm{Na}_{2} \mathrm{O}\right.$ as a percent of ash is 8.8 vs 2.8 ), this material has more ash (dry basis) and its ash has more potassium and silicon and less calcium and magnesium (although the calcium and magnesium concentrations on a dry coal basis are similar for the two coals). The high-sodium coal also has less volatile matter (dry basis). The analyses of both samples were supplied to Coteau Properties. Microautoclave experiments with the high-sodium North Dakota lignite (Table 1) at $350^{\circ} \mathrm{C}, 60 \mathrm{~min}$, hydride ion reagent "A"/dry coal: 0.9 or 1.1 , solvent/dry coal: 1.8 or 2.2 (Runs 70 and 85 ) gave a coal conversions of 63.8 or 64.1 wt \%, about 8 wt \% lower than with the lower sodium sample that has been used up to this time. Shorter residence time at $350^{\circ} \mathrm{C} \mathrm{(45} \mathrm{min,} \mathrm{Run} 86$ ) gave a coal conversion about $15 \mathrm{wt} \%$ lower than that which had been obtained with the low-sodium content sample under the same conditions. At $375^{\circ} \mathrm{C}$ and 45 min (Run 87), coal conversion was about 5 wt \% lower than had been obtained with the low-sodium content lignite.

Microautoclave runs with Black Thunder Mine coal continued this quarter. A test made with Black Thunder Mine coal for $150 \mathrm{~min}$ at $400^{\circ} \mathrm{C}$, hydride ion reagent "A"/dry coal ratio: 1 , and solvent/dry coal ratio: 2 gave a coal conversion of $86.4 \mathrm{wt} \%$, nearly the same conversion obtained at the same conditions but at times of 30,45 , and $60 \mathrm{~min}(86.7,87.5$, and $86.7 \mathrm{wt} \%$, respectively). Coal conversions also were obtained for tests made at short 
residence time ( $15 \mathrm{~min}$ ) at both $375^{\circ} \mathrm{C}$ and $400^{\circ} \mathrm{C}$ (Runs 91 and 92 gave coal conversions of 62.5 and 79.7 wt \%, respectively).

Three microautoclave runs were made with Black Thunder coal to obtain mass and elemental balances and to determine the product quality of materials produced under different reaction conditions (Runs $73,74 \mathrm{~b}$, and 76, Table 2). Total gas pressure and weight (by loss on venting) were determined; the gases were sampled and analyzed by gas chromatography. The low-boiling component of the products were distilled directly from the microautoclave at $120^{\circ} \mathrm{C}$ at atmospheric pressure. The undistilled material was pressure filtered with THF. The THF-solubles were distilled to $290^{\circ} \mathrm{C}$ at 5 torr $\left(488^{\circ} \mathrm{C}\right.$ atmospheric equivalent) to remove the V1074 solvent. Analyses of the low-boiling component of the products distilled directly from the microautoclave at atmospheric pressure and $120{ }^{\circ} \mathrm{C}$ were performed by ${ }^{1} \mathrm{H}-\mathrm{NMR}$ spectrometry and GC/MS. Coal conversions obtained from pressure filtration with THF of the $120{ }^{\circ} \mathrm{C}+$ fraction were 82.6 wt \%, 86.9 wt \%, and 89.8 wt \%, respectively. The value obtained for Run $74 \mathrm{~b}$ confirms that obtained for a run made previously under the same conditions (Run 20). A replicate of Run 76 (Run 76b) gave a similar coal conversion of $90.5 \mathrm{wt} \%$. The GC/MS analysis of the $488^{\circ} \mathrm{C}$ - distillate of the THF-solubles from Run 73 shows it to be very similar to that of the starting V1074 solvent. Distillates, pot bottoms, and THF-insolubles for Runs $73,74 b$, and 76 were submitted for elemental analyses. The elemental analyses of the soluble resid products $\left(488^{\circ} \mathrm{C}^{+}\right.$material) from these tests show them to be enriched in hydrogen relative to the feed coal; the $\mathrm{H} / \mathrm{C}$ ratios are 0.80 for the feed coal, 0.99 for Run $73,0.92$ for Run 76 , and 0.89 for Run $74 \mathrm{~b}$. Samples of these materials were sent to UKICAER for sim-dist analysis.

A sample of North Dakota lignite from the Glenharold Mine was obtained. Tests were made with this coal, hydride ion reagent " $\mathrm{A}$ ", at two different hydride ion reagent to dry coal ratios (0.9 and 1.1) and Wilsonville Run 262E V1074 solvent at two different solvent to dry coal ratios (1.8 and 2.2) at 350,375 , and $400{ }^{\circ} \mathrm{C}$ for $45 \mathrm{~min}$; coal conversions obtained were $67.4,85.4$, and $91.9 \mathrm{wt} \%$, respectively on an $\mathrm{SO}_{3}$-free MAF coal basis for hydride ion reagent to dry coal ratio of 0.9 and $68.1,85.3$, and 92.6 wt $\%$, respectively, for tests made with a hydride ion reagent to dry coal ratio of 1.1 (Table 3 ). These are higher coal 
conversions than those obtained with a sample of high-sodium content Freedom Mine North Dakota lignite under similar conditions (Table 1).

A microautoclave run (Run 94) was made with Glenharold Mine coal to which water was added to obtain an equivalent moisture content of $33 \mathrm{wt} \%$ and the total charge to the reactor was raised to $22.5 \mathrm{~g}$ from the $17 \mathrm{~g}$ used to date in this program; a coal conversion of 92.8 wt \% was obtained. The run was repeated (Run 94b); coal conversion obtained for the replicate was $92.5 \mathrm{wt} \%$ (Table 4). Eight tests were made to determine what factor (total pressure, water content, coal composition, or solvent composition) causes this high coal conversion. Three tests used Glenharold Mine lignite, three used the high-sodium content sample of Freedom Mine lignite, and two used Black Thunder Mine subbituminous coal (Table 4).

Within the range of solvent-to-coal ratios studied (2.4 to 2.9) there was no apparent effect of solvent to dry coal ratio on coal conversion, nor was there any influence noted by using the higher boiling $\left(488^{\circ} \mathrm{C}^{+}\right)$portion of the $\mathrm{V} 1074$ solvent. System pressure was elevated by reducing the head space in the reactor by introducing more reactants and by increasing the amount of water present in the system by increasing the water to coal ratio. Coal conversion was found previously to be dependent on hydride ion to coal ratio; this dependence also was found when the total water to coal ratio was elevated and the total (calculated) reaction pressure was raised.

The effect of reduced head space and increased water content was to raise coal conversions 10 to $20 \mathrm{wt} \%$ (absolute) with the Glenharold Mine lignite and the high-sodium Freedom Mine lignite. No increase in coal conversion was observed for the Black Thunder Mine subbituminous coal. However, the total calculated pressures at reaction temperature for the two Black Thunder Mine coal runs (3260 psi and 3060 psi, respectively) were lower than for any of the Glenharold lignite tests and for the two runs which gave the highest coal conversions with the high-sodium lignite (>3300 psi). This difference will be further investigated. 


\section{One-Liter Autoclave}

Construction was completed on the one-liter autoclave system. Specifically, a highpressure monitoring window was installed in the barricade wall and the thermocouple switch box and monitor were mounted. The malfunctioning Magnedrive assembly was rebuilt and a guard was constructed and placed around its belt drive. The Neslab chiller/recirculator, which provides cooling water for the reactor and the Magnedrive stirrer, was repaired. A city water line with a back-flow preventer valve was plumbed in for backup service. A line for venting and rupture disc relief which terminates in a catch pot on the roof was installed. Vapor condensation and gas collection systems were installed. Gas collection vessels were recovered from storage and were cleaned, pressure tested, and calibrated. The high pressure $\mathrm{N}_{2}$ tank (used for pressure testing) was located outside the barricade; a steel mesh guard was installed around the top of the tank and regulator. The front of the guard is faced in Plexiglas as an added protection in the event of a sudden discharge of the tank at the fittings or blowout of a pressure gauge. Approval was received for the Safety Manual and Standard Operating Procedure.

Two successful tests were made in the one-liter unit. Conditions for the runs were those chosen at the March 6, 1996, quarterly review meeting (Table 5). The $120^{\circ} \mathrm{C}^{-}$fraction was distilled from the reaction products. Grab samples (ca. $10 \mathrm{~g}$ ) of the $120^{\circ} \mathrm{C}^{+}$material were filtered with THF and are being analyzed for ash content to determine coal conversion. The remainder of the $120^{\circ} \mathrm{C}^{+}$material will be shipped to UK early next quarter.

\section{Filtration}

Five microautoclave product samples prepared from Black Thunder coal at solvent-to-coal ratios of 1 and 1.5 were received from CONSOL (Runs 21,52a and 52b, and 53a and 53b); two were filtered. Conversions were calculated based on both the THF-insolubility of the filter cakes and ash enrichment methods (rather than on the basis of THF-insolubles determined for a separate batch run). Little difference was found in conversion between the runs (Runs 52 and 53), which differed only in solvent-to-coal ratios ( 87 wt \% and 86 wt $\%$ at $1: 1$ and $1.5: 1$ solvent-to-coal ratios, respectively). The filtration rate at the lower solvent-to-coal ratio was slower, but when allowance is made for the higher coal concentration in the sample, then the rates of extract separation are similar. 
Filtrations of the duplicate samples were performed. The rates of filtration were close to those of the original samples. As decided at the recent quarterly review meeting on March 6, 1996, all of the filtrates from Black Thunder runs at $375^{\circ} \mathrm{C}$ and $400{ }^{\circ} \mathrm{C}$ were composited to produce a single sample of about $30 \mathrm{~g}$. This sample was vacuum distilled to an equivalent temperature of $410^{\circ} \mathrm{C}\left(770^{\circ} \mathrm{F}\right)$ at atmospheric pressure. This gave a feedstock of about $10 \mathrm{~g}$ with a $566{ }^{\circ} \mathrm{C}^{+}\left(1050^{\circ} \mathrm{F}^{+}\right)$content of about $70 \%$ for use in four hydrotreating tests.

\section{Hydrotreating}

In preparation for the hydrotreating study using filtrates from the first-stage liquefaction step, a deashed resid from Wilsonville Run 258A was used to study the activation of Mo catalyst precursors. The three catalyst precursors studied were Molyvan $L$, molybdenum naphthenate, and powdered AO60 (sulfided both in situ and ex situ). One hour experiments were conducted at $440{ }^{\circ} \mathrm{C}$, both with and without pretreatment at $375^{\circ} \mathrm{C}$ for 30 minutes. In all cases except for the AO60 sulfided in situ, resid conversions and hydrogen uptake were very similar. A repeat of this latter run showed resid conversion for the supported catalyst to be somewhat better than with the dispersed organometallics. Of the dispersed catalyst precursors studied, it was suggested that Molyvan L was slightly more active based on higher hydrogen consumption.

In the proposed novel liquefaction scheme, the use of dispersed catalysts for hydrotreating introduces several attractive options, so extended study of the selected organometallic Mo precursor, Molyvan L, was performed this quarter. A series of experiments was carried out in microautoclaves; the reactor was charged with three grams of Wilsonville Run 258A deashed resid and $1000 \mathrm{ppm}$ of Mo, added as Molyvan L. The reaction mixtures were pretreated under six conditions ( 5 and 30 minutes at 300,340 , and $375^{\circ} \mathrm{C}$ ), followed by reaction at $440{ }^{\circ} \mathrm{C}$ for 60 minutes. Cold reactor pressure was 1450 psig total, with $2 \%$ $\mathrm{H}_{2} \mathrm{~S}$. Duplicate and sometimes triplicate runs were performed for this run matrix. With good precision in these experiments, no impact was seen on either resid conversion or hydrogen uptake. Over the range of conditions tested, pretreatment has shown no discernable effect on Molyvan L catalyst activity. 
In addition to catalyst activation studies, reaction time and temperature were investigated in preparation for testing with first-stage filtrates. The baseline reaction conditions to date have been 60 minutes at $440{ }^{\circ} \mathrm{C}$. Experiments were performed this quarter at 30 and 90 minutes which showed that resid conversion generally proceeds according to first-order kinetics. Additionally, 60 -minute runs were conducted at $400{ }^{\circ} \mathrm{C}$; these tests showed both reduced hydrocarbon gas production and reduced resid conversion. Finally, experiments were performed to examine the reactivity of the catalyst following reaction at 60 minutes. Analysis of these data is incomplete. Hydrotreating tests will be conducted next quarter on the composited filtrates described above.

\section{Simulated Distillation of Coal-Derived Materials}

The high-temperature simulated distillation apparatus was installed by the vendor (AC Analytical Controls, Bensalem, PA) this quarter. The instrument contains a $5 \mathrm{~m}$ aluminumclad, fused-silica, capillary column with a $0.09 \mu \mathrm{m}$ coating of methylsilicone. The column is designed for oven temperatures of up to $430^{\circ}$. The instrument was calibrated within the vendor's specifications. However, the instrument does not have an auto-sampler, so the measured elution masses are not expected to be accurate. In addition, manual injections will limit the number of complete sample analyses to four per day because of the extensive calibration procedure that is required.

A number of samples from the hydrotreating study were analyzed. As expected, the aromaticity of these samples caused the boiling curves to be shifted toward lighter fractions. To correct for this, an aromatic calibrant was utilized in order to establish a correction for the paraffinic calibrant that is a part of the vendor's standard method. Preliminary results using the aromatic calibrant are consistent with values obtained using vacuum distillation of the coal-derived liquids (modified ASTM D1160).

Samples from Wilsonville Run 259 , Period $\mathrm{G}$ were analyzed by the new high-temperature sim-dist equipment for comparison to the sim-dist results reported by Wilsonville; V161 and V182 materials were tested. The V161 material was too low-boiling to get accurate results by the high temperature method. The results for the $\mathrm{V} 182$ sample were very similar 
to those reported by Wilsonville. The aromatic calibration provided the closest match to the Wilsonville results.

\section{Task 5 - Engineering and Economic Study}

LDP Associates continued the review of the technical and patent literature on hydride transfer agents. Additions to the annotated bibliography were completed and the second update was issued. Several key articles were identified. In an effort to elucidate the chemical mechanisms of the proposed process, the elemental analyses of the microautoclave material balance tests (Runs $73,74 b$, and 76 ) were begun.

\section{Task 6 - Reporting}

Bi-monthly conference calls were held as scheduled with UKJCAER and LDP. Reports documenting the calls were issued. The third quarterly review meeting was held on March 6, 1996, at CONSOL in Library, PA; a meeting report was issued. The scheduled quarterly conference call with DOE was held on March 22, 1996. A conference record was issued. 
TABLE 1 RESULTS OF MICROAUTOCLAVE TESTS MADE WITH HIGH-SODIUM COTEAU PROPERTIES, FREEDOM MINE, NORTH DAKOTA LIGNITE, HYDRIDE ION REAGENT "A",

\section{AND WILSONVILLE 262E V1074 SOLVENT}

\begin{tabular}{|c|c|c|c|c|c|}
\hline Run No. & $\begin{array}{c}\text { Time } \\
\min \end{array}$ & $\begin{array}{c}\text { Temp., } \\
{ }^{\circ} \mathrm{C}\end{array}$ & $\begin{array}{c}\text { Hydride ion } \\
\text { reagent/dry coal }\end{array}$ & $\begin{array}{c}\text { Solvent/ } \\
\text { dry coal }\end{array}$ & $\begin{array}{c}\text { Coal Conversion, } \\
\text { wt \%* }\end{array}$ \\
\hline \hline 70 & 60 & 350 & 0.9 & 1.8 & 63.8 \\
\hline 85 & 60 & 350 & 1.1 & 2.2 & 64.1 \\
\hline 86 & 45 & 350 & 1.1 & 2.2 & 57.0 \\
\hline 87 & 45 & 375 & 1.1 & 2.2 & 76.7 \\
\hline
\end{tabular}

* Conversion on moisture and $\mathrm{SO}_{3}$-free-ash free basis

TABLE 2. RESULTS OF MICROAUTOCLAVE TESTS MADE WITH BLACK THUNDER MINE WYOMING SUBBITUMINOUS COAL, HYDRIDE ION REAGENT "A", AND WILSONVILLE RUN 262E V1074 SOLVENT

\begin{tabular}{|c|c|c|c|c|c|}
\hline $\begin{array}{c}\text { Run } \\
\text { No. }\end{array}$ & $\begin{array}{c}\text { Time } \\
\text { min }\end{array}$ & $\begin{array}{c}\text { Temp., } \\
{ }^{\circ} \mathbf{C}\end{array}$ & $\begin{array}{c}\text { Hydride ion } \\
\text { reagent/dry coal }\end{array}$ & $\begin{array}{c}\text { Solvent } \\
\text { dry coal }\end{array}$ & $\begin{array}{c}\text { Coal Conversion, } \\
\text { wt \%* }\end{array}$ \\
\hline \hline 73 & 150 & 350 & 1.0 & 2.0 & 83.4 \\
\hline $74 \mathrm{~b}$ & 45 & 400 & 1.0 & 2.1 & 88.7 \\
\hline 75 & 150 & 400 & 2.1 & 1.0 & 85.9 \\
\hline 76 & 150 & 375 & 1.0 & 2.0 & 89.8 \\
\hline $76 \mathrm{~b}$ & 150 & 375 & 1.0 & 2.0 & 90.5 \\
\hline 91 & 15 & 400 & 1.0 & 2.1 & 62.5 \\
\hline 92 & 15 & 375 & 1.0 & 2.1 & 79.7 \\
\hline
\end{tabular}

- Conversion on moisture and $\mathrm{SO}_{3}$-free-ash free basis

TABLE 3. RESULTS OF MICROAUTOCLAVE TESTS MADE WITH GLENHAROLD MINE NORTH DAKOTA LIGNITE, HYDRIDE ION REAGENT "A", AND WILSONVILLE RUN 262E V1074 SOLVENT

\begin{tabular}{|c||c|c|c|c|c||}
\hline $\begin{array}{c}\text { Run } \\
\text { No. }\end{array}$ & $\begin{array}{c}\text { Time } \\
\min \end{array}$ & $\begin{array}{c}\text { Temp., } \\
{ }^{\circ} \mathrm{C}\end{array}$ & $\begin{array}{c}\text { Hydride ion } \\
\text { reagent/dry coal }\end{array}$ & $\begin{array}{c}\text { Solvent } \\
\text { dry coal }\end{array}$ & $\begin{array}{c}\text { Coal Conversion, } \\
\text { wt \%* }\end{array}$ \\
\hline \hline 81 & 45 & 350 & 0.9 & 1.8 & 67.4 \\
\hline 79 & 45 & 375 & 0.9 & 1.8 & 85.4 \\
\hline 78 & 45 & 400 & 0.9 & 1.8 & 91.9 \\
\hline 82 & 45 & 350 & 1.1 & 2.2 & 68.1 \\
\hline 83 & 45 & 375 & 1.1 & 2.2 & 85.3 \\
\hline 84 & 45 & 400 & 1.1 & 2.2 & 92.6 \\
\hline
\end{tabular}

- Conversion on moisture and $\mathrm{SO}_{3}$-free-ash free basis 
TABLE 4. RESULTS OF MICROAUTOCLAVE TESTS MADE AT ELEVATED PRESSURE

Total Reactor Charge $22.5 \mathrm{~g}$

Water added to equivalent of $33 \mathrm{wt} \%$ of coal

\begin{tabular}{||c||c|c|c|c|c|c||}
\hline $\begin{array}{c}\text { Run } \\
\text { No. }\end{array}$ & Coal (a) & $\begin{array}{c}\text { Time } \\
\text { min }\end{array}$ & $\begin{array}{c}\text { Temp., } \\
{ }^{\circ} \mathrm{C}\end{array}$ & $\begin{array}{c}\text { Hydride ion reagent } \\
\text { "A"/dry coal }\end{array}$ & $\begin{array}{c}\text { Solvent } \\
\text { dry coal }\end{array}$ & $\begin{array}{c}\text { Coal Conversion, } \\
\text { wt \% (b) }\end{array}$ \\
\hline 94 & G & 60 & 350 & 1.5 & $2.9(\mathrm{c})$ & 92.8 \\
\hline $94 \mathrm{~b}$ & $\mathrm{G}$ & 60 & 350 & 1.5 & $2.9(\mathrm{c})$ & 92.5 \\
\hline 96 & $\mathrm{G}$ & 60 & 350 & 1.5 & $2.9(\mathrm{~d})$ & 92.8 \\
\hline 97 & G & 60 & 350 & 1.0 & $2.9(\mathrm{c})$ & 89.5 \\
\hline 98 & G & 60 & 350 & 1.0 & $2.4(\mathrm{c})$ & 90.1 \\
\hline 99 & HS-FM & 60 & 350 & 1.5 & $2.4(\mathrm{c})$ & 83.1 \\
\hline 100 & HS-FM & 60 & 350 & 1.5 & $2.4(\mathrm{~d})$ & 82.5 \\
\hline 101 & HS-FM & 60 & 350 & 1.0 & $2.4(\mathrm{c})$ & 74.1 \\
\hline $102 \mathrm{~b}$ & BT & 60 & 350 & 1.5 & $2.4(\mathrm{c})$ & 80.4 \\
\hline 103 & BT & 60 & 350 & 1.0 & $2.9(\mathrm{c})$ & 73.9 \\
\hline
\end{tabular}

(a) Coal: G: Glenharold Mine lignite; HS-FM: high-sodium, Freedom Mine lignite; BT: Black Thunder Mine, subbituminous

(b) Conversion on moisture and $\mathrm{SO}_{3}$-free-ash free basis

(c) Wilsonville Run 262E, whole V1074

(d) Wilsonville Run $262 E, 488^{\circ} \mathrm{C}$ portion of V1074

TABLE 5. ONE-LITER AUTOCLAVE TEST CONDITIONS*

\begin{tabular}{||l|c|c|}
\hline & Run 4 - LA & Run 5 - LA \\
\hline \hline Temperature, ${ }^{\circ} \mathrm{C}$ & 400 & 350 \\
\hline Residence Time (at Temperature), min & 45 & 150 \\
\hline Black Thunder Mine Coal, g & 100 & 100 \\
\hline Wilsonville Run $262 \mathrm{E}, \mathrm{V} 1074,488^{\circ} \mathrm{C}, \mathrm{g}$ & 120 & 120 \\
\hline
\end{tabular}

" Hydride ion reagent "A" used for both tests 